\title{
Multidrug resistance-associated ABC transporters - too much of one thing, good for nothing
}

\author{
Jirina Prochazkova*, Martina Lanova \\ and Jiri Pachernik
}

Department of Animal Physiology and Immunology, Faculty of Science, Masaryk University, Kotlarska 2, CZ-611 37 Brno, Czech Republic

* Corresponding author
e-mail: jipro@sci.muni.cz

\begin{abstract}
Overexpression of ATP-binding cassette (ABC) transporters in cancer cells results in multidrug resistance (MDR) which leads to unsuccessful chemotherapy. The most important MDR-associated members of $\mathrm{ABC}$ superfamily are $\mathrm{ABC}$ B1/P-glycoprotein/MDR1, $\mathrm{ABC} \mathrm{C} 1 /$ multidrug resistance associated protein 1 (MRP1), and ABC G2/BCRP. This study is not only focused on function, substrates, and localization of these popular proteins but also on other $\mathrm{ABC} C$ family members such as ABC C2-6/MRP2-6 and ABC C7/CFTR. Current research is mainly oriented on the cancer-promoting role of these proteins, but important lessons could also be learned from the physiological roles of these proteins or from polymorphisms affecting their function. Thorough knowledge of structure and detailed mechanism of efflux can aid in the discovery of new chemotherapy targets in the future. Although the best way on how to deal with MDR would be to prevent its development, we describe some new promising strategies on how to conquer both inherited and induced MDRs.
\end{abstract}

Keywords: ABC transporters; barrier; multidrug resistance; polymorphism; substrate.

\section{Introduction}

Active mechanisms that allow distribution of ions against their gradient were well studied mainly in marine physiology in the 1950s (1). In the 1960s, membrane-bound ATP-driven ion pumps were described $(2,3)$. ATP-utilizing proteins allowing active transport of larger molecules in bacteria and yeast were found later (e.g., maltose-binding proteins) (4). Those ubiquitous transporters were named $\mathrm{ABC}$ transporters to connote their specific ATP-binding cassette $(5,6)$. This field gained importance when the harmful role of these overexpressed transporters was recognized in cancer cells. The ability of
P-glycoprotein (later named ABC B1) to efflux multiple chemotherapeutic drugs caused the so-called multidrug resistance (MDR) of cancer cells and, consequently, the relapse of illness (7) [reviewed in (8)]. Now after more than 20 years, the research has involved the description of almost 50 various mammalian $\mathrm{ABC}$ transporters - their structure, mechanism of function, and main regulatory pathways [reviewed in (9)]. The whole ABC superfamily, however, includes more than 100 different transport proteins found from bacteria to humans; the mammalian $\mathrm{ABC}$ transporters are exquisitely exporters (with the only exception of $\mathrm{ABC}$ C7), but the bacterial ones are also able to import [reviewed in (10)]. This review is focused on the nine 'double-edged' $\mathrm{ABC}$ transporters [ABC B1/P-glycoprotein/MDR1, ABC C1-6/MRP1-6, $\mathrm{ABC} C 7 /$ cystic fibrosis transmembrane regulator (CFTR), and $\mathrm{ABC}$ G2/breast cancer resistance protein (BCRP)] which are localized on barrier-like types of tissues where they play the 'sentinel' role; however, they are connected to the phenomenon of MDR and thus could be extremely deleterious.

\section{Structure and evolution}

ABC transporters consist mainly of transmembrane domains (TMDs) that form the 'pore' and have affinity for particular substrates, and cytosolic domains binding the ATP nucleotide [nucleotide-binding domain (NBD)]. The domains are connected by cytosolic and extracellular loops; the latter being often glycosylated. The cytosolic regions of the TMDs are thought to coordinate ATP coupling with substrate binding and translocation. The NBDs contain the characteristic Walker A, B motifs and the 'signature motif,' participating to create the 'pocket' for ATP binding. All those sequences are either involved directly in ATP binding and hydrolysis or they facilitate interfaces in the assembled transporter. All the conserved domains together form a hydrophilic pore closed on the internal cytosolic side, thus creating an aqueous compartment inside the hydrophobic membrane bilayer [for more details, see (9)]. Generally, we can classify ABC transporters either according to their sequence homology to the families (ABC A-G) or structurally to half- and full-transporters. The full-transporters (typical example is $\mathrm{ABC} \mathrm{B} 1$ protein) have two TMDs and NBDs. As the name indicates, the halftransporters (represented by ABC G2) consist of only one TMD and NBD [reviewed in (11)].

For the proper assembly of transporting 'pores,' the typical number of involved TMDs is 12 . The half-transporters 
therefore have to homo- or heterodimerize. ABC G2 with only one TMD was evidenced to exquisitely create homodimers. Structural studies revealed that this TMD is not an analog of any of the two domains of ABC B1 as the helices are longer and thus resemble more the Staphylococcus aureus transporter Sav1866. The classical full transporters have a typical pattern of domain arrangement N-terminus - TMD1 - NBD1 - TMD2 - NBD2 - C-terminus, e.g., ABC B1, ABC C4, and ABC C5 (12-14), respectively (see Figure 1). However, $\mathrm{ABC}$ G2 has an NBD on the N-terminal side of the domain, and the linker sequence between NBD and TMD of ABC G2 is highly homologous to the linker sequence between NBD1 and TMD2 of $\mathrm{ABC} B 1$, which may illustrate the complicated process of evolution (15) (Figure 1). ABC C1-3 and ABC C6 have an additional N-terminal TMD consisting of five helices, which seems to be associated with their ability to efflux bulky conjugates, as the members of $\mathrm{ABC} C$ family that transport relatively smaller nucleosides ( $\mathrm{ABC} \mathrm{C} 4$ and ABC C5) do not contain this extra domain (16-19). ABC C7, composed of 12 transmembrane helices, has also one special domain, but it is located in the cytosol and probably has a regulatory function (20).

Evolutionists suppose that originally, the half-transporters emerged first and the full-transporters evolved by multiplication. The comparison of multiple variants of ABC B5 gene, however, revealed that those full-transporters could later lose some sequences, and in the end, they remind more the structure of half-transporters (21). The study in bacteria also showed that the typical structure of ABC transporters was probably formed when ATPase non-covalently associated with some membrane proteins became involved in transport - usually import of nutrients $(5,22)$. The $\mathrm{ABC}$ transporters are one of the most conserved proteins even though their genes are extremely flexible as they adapted to an extensive number of substrates during evolution and till now are able to efflux even the man-made compounds. It is supposed that MDRrelated members evolved from a physiologically important member thanks to the higher occurrence of a toxic substrate and simultaneously occurring polymorphism or multiplication of a particular gene. Moreover, when a transporter is lost by mutation, this loss is at least partially compensated by a related transporter with an overlapping function. As a result, the knockout of a particular $\mathrm{ABC}$ transporter is rarely

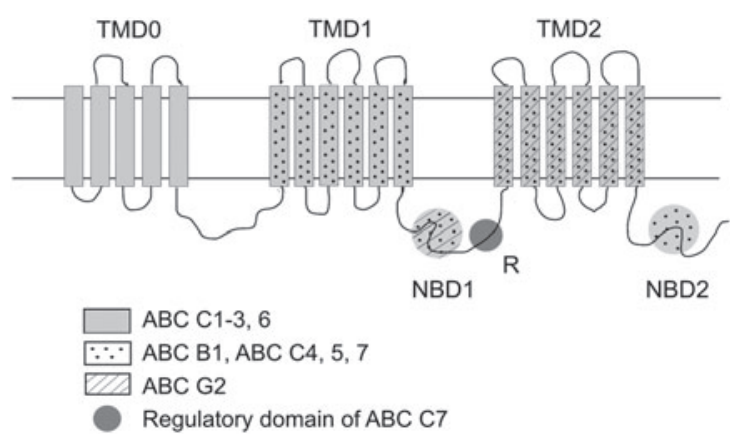

Figure 1 Schematic overlay of structural features of MDRassociated $\mathrm{ABC}$ transporters. lethal even though the $\mathrm{ABC}$ transporters are one of the oldest and highly expressed of all the proteins $(23,24)$. So far, 32 murine knockouts of $\mathrm{ABC}$ transporters were made and only five of them resulted in embryonic ( $A B C B 7$ and $A B C E 5)$ or early postnatal ( $A B C A 3, A B C A 12$, and $A B C C 9$ ) lethality. $A B C B 7$ knockout embryos die due to collapse of mitochondrial respiration process (25). Embryonic lethality was also described in $A B C E 5^{-1-}$ mice, which is understandable as this transporter plays an important role in ribosome binding and recycling. $A B C A 3$ newborn knockout mice die due to lack of surfactant in lungs and following respiratory failure (26). $A B C A 12$ knockouts are also lethal because of severe lung and skin defects (27). Mice lacking $A B C C 9 /$ Sur2 regulating sulfonylurea metabolism die of cardiac failure soon after birth (28). The current status of scientific progress in knockouts could be monitored at the Mouse Genome Informatics (http://www.informatics.jax.org).

\section{Mechanism of drug efflux}

The Mechanism of drug efflux is best examined in $\mathrm{ABC}$ B1 protein; however, the detailed mechanism has not yet been revealed. The most significant difference between the two currently acknowledged models is the source of the power that drives the drug from a high-affinity site to a lowaffinity site. In one model, the formation of the ATP-containing NBD dimer results in conformational changes that decrease the affinity of the substrate in the drug binding site and thus release the substrate. Two sequential ATP hydrolysis events then reset the ATP molecule. The second model also requires two ATP hydrolysis events, but one powers the efflux of the drug and the other resets the protein to its ground state (29). Both of these models refer to the 'alternating catalytic sites' scheme. The main point is that only one of the two NBDs hydrolyzes ATP at any given time and the two NBDs alternate during the catalytic cycle [for details, see (30)].

One of the most intriguing issues in $\mathrm{ABC}$ transporter field is what affects the specificity of transporter-substrate affinity as one protein could have a plethora of non-relative substrates. Drugs that are able to bind into a hydrophobic pocket on the transporter can interact through a few polar residues strongly enough to trigger catalysis or a productive transport ATPase cycle without a precise fit. The affinity is increased many hundred-folds when hydrophobic compounds concentrate on the surface of the membrane compared to the solvent concentration. Affinity of a drug for, e.g., $A B C B 1$ could be predicted from the number of suitably spaced pairs or triplets of electron-donor groups on its hydrophobic backbone. The concentration and orientation of substrate in the membrane and isolation from competing solvent molecules afforded by the membrane thus allow interactions with a relatively high $\mathrm{K}_{\mathrm{m}}$ to occur with significant frequency and specificity (31). The correlation between a specific property of the substrate and the TMD size was found in bacteria. The general principle claiming 'the larger the substrate, the longer is the TMD sequence' seems to be reasonable because larger substrates would require a larger diameter of transmembrane channel (32). 


\section{Regulation of expression}

Expression of $\mathrm{ABC}$ transporters is regulated at multiple levels - transcriptional level is influenced both by genetic and epigenetic means, post-transcriptional level is represented by changes in mRNA stabilization and translation initiation (33), and post-translational level involves cytoplasm-membrane trafficking and consecutive glycosylation. Constitutive, basal transcription of MDR proteins could be extensively potentiated by stressors as are hypoxia, inflammation, or activation of glucocorticoid or cytokine receptors [reviewed in (34)]. Those agents usually trigger stress or receptor-associated kinase cascades, which in turn activate transcription factors Sp1, HSP, MEF1, TCF/LEF, NFאB, and AP1 that have their response elements in proximal promoter $(33,35)$. Transcription of ABC transporters could also be upregulated by a distal element enhanceosome. This area, which spans -10000 bp upstream, is the target for other transcription factors activated by chemotherapeutics, differentiation agents, and DNA-damaging drugs and thus represents one of the mechanisms of induced MDR (36-38).

The phosphoinositide 3-kinase (PI3K) pathway is extremely important for the expression of $\mathrm{ABC}$ transporters and not only on a transcriptional level as the stability of mRNA could be influenced by the availability of components of translational machinery, e.g., eukaryotic initiation factor 4E-binding protein (eIF4E) that requires active PI3K to stay active. In a case of eIF4E shortage, the $5^{\prime}$ end of $A B C B 1$ mRNA becomes extensively folded, which reduces its competitive ability for the translational machinery $(39,40)$. Moreover, PI3K also affects the post-translational level of control as inhibition of $\mathrm{PI} 3 \mathrm{~K} / \mathrm{Akt}$ results in translocation of $\mathrm{ABC}$ transporters from membrane to cytosol and thus in decreased function of the transporter $(41,42)$. Besides, phosporylation and glycosylation occurs in the endoplasmic reticulum. N-glycosylation at Asn596 was described to affect the folding process and thus the stability of the protein. This process is monitored by quality control machinery with the involvement of Derlin-1 protein, a homolog of Drosophila Der1 $(43,44)$. Properly folded proteins are multiglycosylated in Golgi apparatus and then exported to cytoplasmic membrane [reviewed in (45)]. The post-translational modification is best described in ABC G2, but similar $\mathrm{N}$-glycosylation was observed also in $\mathrm{ABC} \mathrm{B} 1$ and $\mathrm{ABC} C 2$ proteins, and thus we can suppose the common validity of these mechanisms (46).

\section{Physiological features of MDR-associated ABC transporters}

\section{ABC B1}

ABC B1 substrates are usually hydrophobic, lipid-soluble positively charged, or neutral natural products, including some chemotherapeutic agents (e.g., taxanes, anthracyclines, and vinca-alkaloids) and steroids. Substrates can bind to at least two sites in the TMDs that interact in a positively cooperative manner (12). Interactions between cholesterol of cytoplasmic membrane and $\mathrm{ABC} \mathrm{B} 1$ are remarkable. Cholesterol affects both drug efflux ability and phospholipid flippase functions of ABC B1. Increase in cholesterol content greatly alters the partitioning of hydrophobic drug substrates into the membrane and thus MDRs (47).

Mutational analysis revealed over 50 polymorphisms in $A B C B 1$ gene; the research focused on two most abundant polymorphisms G2677T in 21st exon and C3435T in 26th exon. Both polymorphisms are synonymous and localized in extracellular loops between TMDs (48). In the site 2677, the missense polymorphism G2677A can also be found. However, even the silent polymorphism results in a different conformation of the protein and thus changes the substrate affinity (49, 50). Interestingly, the polymorphisms in 3435 and 2677 sites very often occur simultaneously $(51,52)$. Those two polymorphisms are scrutinized to correlate with different diseases or reaction to treatment. Positive correlation is usually found when it concerns the steroid metabolism $(52,53)$. Tens of studies were performed to assess the correlation of polymorphisms and outcomes or recurrence of different tumors but generally with inconsistent results. So far, the only positive study was performed on ovarian cancer treated with paclitaxel/carboplatin and demonstrated that compared to normal homozygote 2677GG, women with the minor T/A alleles were significantly less likely to relapse following treatment (54).

Polymorphism of $A B C B I$ may also be involved in Alzheimer's disease as it was shown to efflux amyloid- $\beta$. Experimental models showed that inhibition of $\mathrm{ABC} B 1$ results in increased accumulation of amyloid- $\beta$ in the brain. Nevertheless, polymorphisms G2677T/A and C3435T were not in correlation with the occurrence of Alzheimer's disease in patients. Still, a possible effect of rare deleterious variants is worthy of further investigation (55). Involvement of $\mathrm{ABC}$ B1 in Parkinson's disease is also possible as patients with the earliest onset have the lowest function of ABC B1 (56).

\section{ABC C family}

The majority of the $\mathrm{ABC} \mathrm{C}$ family proteins are associated with MDR (ABC C1-6, 10-12), but this family also includes $\mathrm{ABC}$ C7, which is a cystic fibrosis transmembrane conductance regulator. Furthermore, $\mathrm{ABC} \mathrm{C} 8$ and $\mathrm{ABC} \mathrm{C} 9$ are the sulfonylurea receptors, which constitute the ATP-sensing subunits of a complex potassium channel. The novel ABC C13 is a pseudo-gene, which product lacks a transporting activity. In this review, we describe the features of well-studied members of $\mathrm{ABC} C$ family $\mathrm{ABC} \mathrm{C} 1-7$. This family specializes in the transport of organic anions, such as drugs conjugated to glutathione, sulfate or glucuronate, and several glucuronosyl-, or sulfatidyl steroids [reviewed in (57)]. ABC C proteins are effective also in plants where they work as vacuolar pumps of glutathione- $S$ conjugates. There is evidence showing their involvement in the processes of detoxification and heavy metal sequestration, or chlorophyll catabolite transport and ion channel regulation [for details, see (58)].

ABC C1 $\mathrm{ABC} \mathrm{C} 1$ is known to efflux an important immunomodulator leukotriene $\mathrm{C}(4)$ from its source (i.e., mast cells). ABC C1 thus plays an important role in the development 
of inflammation, e.g., allergic airway inflammation and dendritic cell mobilization $(59,60)$. Moreover, ABC C1deficient mice have also impaired differentiation of dendritic cells, which appears to be independent of the leukotriene pathway. The relevant $\mathrm{ABC} \mathrm{C} 1$ substrate, which is required for dendritic cell differentiation, however, remains to be identified (61).

ABC C2, and C3 Highly homologous ABC C2 and C3 are able to efflux amphiphilic anionic conjugates, e.g., bilirubin glucuronides. Insufficient expression of $\mathrm{ABC} C 2$ in apical membrane of hepatocytes results in Dubin-Johnson syndrome, which is characterized by deficiency in the secretion of conjugates into the bile and its excess in blood as $\mathrm{ABC} C 3$ in basolateral membrane tries to compensate this defect (62) (Table 1). The ability of ABC C2 and C3 to cause MDR when overexpressed has probably influenced the less favorable prognosis of breast cancer $(63,64)$.

$A B C$ C4 One of the most interesting members of the $A B C$ $\mathrm{C}$ family is $\mathrm{ABC} C 4$, whose function was initially defined by its ability to confer resistance to nucleoside analogs used as antineoplastic drugs when overexpressed. Physiologically, $\mathrm{ABC}$ C4 transports cyclic nucleotides (cGMP and cAMP); thus, it is part of a biological regulatory loop that occurs when intracellular cAMP levels increase (65). Furthermore, export of cyclic monophosphates may have a paracrine signaling function, as vast biological effects of extracellular cAMP and cGMP have been reported $(66,67)$. Interestingly, $A B C$ C4 forms a macromolecular complex metabolizing cAMP with the help of scaffolding PDZ domain containing protein PDZK1, and what is even more striking, the involvement of ABC C7 protein (described below) was evidenced to be part of this complex (68). $\mathrm{ABC} \mathrm{C4}$ has an ubiquitous pattern of expression, compared to other members of $\mathrm{ABC} C$ family, which are either apically or basolaterally localized (see Table 1). For example, the dual localization of $\mathrm{ABC} \mathrm{C} 4$ at the basolateral membrane of the choroid plexus epithelium and in the apical membrane of the endothelial cells of the brain capillaries efficiently defends the brain from the potentially toxic substances but in turn complicates the treatment of brain malignancies.

Activity of $\mathrm{ABC}$ C4 could be correlated also on the level of splicing of primary transcripts. Intron 1 contains two additional exons bearing evolutionarily conserved premature termination codons. The splicing variants with those codons are, at least partially, targets of non-sense-mediated mRNA decay, which then represents a means on how to downregulate expression of $\mathrm{ABC} C 4$ (69). ABC C4 expression increases when hematopoietic precursors differentiate in megakaryocytes but decreases during maturation of monocytes and granulocytes (70). The ABC C4 transporter is thus highly expressed both in human platelet $\delta$-granules and cytoplasmic membrane and it is involved in ADP release, which is necessary for activation of platelets. Defective expression of platelet $\mathrm{ABC}$ C4 thus results in lack of functional $\delta$-granules, insufficient release of ADP, and thus mild hemophilia (71).

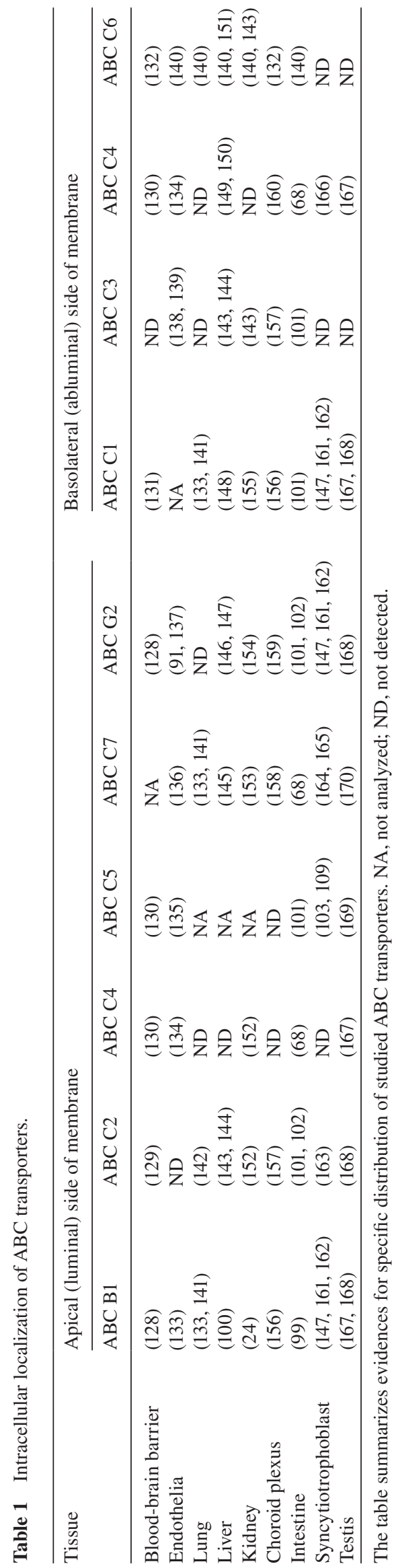


The $A B C C 4$ gene and promoter are highly polymorphic. The TC genotype of the regulatory T-1393C polymorphism is associated with better event-free survival in pediatric acute lymphoblastic leukemia accompanied by lower plasma levels of methotrexate and 6-mercaptopurine, which are $\mathrm{ABC} \mathrm{C} 4$ substrates used for the treatment of this disease. In contrast, the CA genotype of A934C (Lys304Asn) substitution correlated with lower event-free survival and higher frequency of high-grade thrombocytopenia (72). Explanation is probably rather complex as these polymorphisms do not affect the level of transcription or translation. ABC C4 is also important in antiretroviral therapy, as its substrates include nucleotide analogs efficiently used as therapeutics, e.g., 2',3'-dideoxy$3^{\prime}$-thiacytidine (lamivudine) (73). A polymorphism T4131G in $3^{\prime}$ UTR was associated with a desirable $20 \%$ elevated concentration of anti-HIV drug lamivudine in lymphocytes and probably caused by altered splicing and in turn reduced function or expression of this protein (74).

ABC C5 ABC C5 is both genetically and functionally relative to $\mathrm{ABC} \mathrm{C} 4$, but it differs functionally as it does not confer resistance to natural anticancer agents or methotrexate. It participates on the efflux of cyclic nucleosides and their analogs. High expression of ABC C5 was described in bloodtissue barriers, in muscle, blood, and neural cells, which points to its physiological function in signaling processes [reviewed in (75)]. The increased expression of ABC C5 was observed in ischemic cardiomyopathy, which may correlate with the ischemia-induced elevated cGMP level (76). ABC C5 together with $\mathrm{ABC}$ C4 was also observed in striated muscles, and its ability to efflux statins (used to decrease hypercholesterolemia) may help to protect cells from statininduced myopathies (77). Although the gene is highly polymorphic, no correlation with any disease has as yet been described.

ABC C6 ABC C6 protein is involved in the transport of glutathione conjugates and leukotriene E4. Mutations in the $A B C$ C6 gene cause hereditary ectopic mineralization of connective tissues called pseudoxanthoma elasticum, which is inherited in an autosomal recessive manner. It is clinically manifested usually in the skin, the eyes, and the cardiovascular system, i.e., in tissues with only minimal expression of ABC C6 [reviewed in (78)]. Similar manifestations were also seen in dystrophic cardiac calcification, another autosomal recessive disease caused by mutation of $A B C C 6$, characterized by calcium phosphate deposits in myocardial tissue and thus affecting the arterial system in patients with atherosclerosis, diabetes mellitus, and chronic renal failure. The screening of the $A B C$ C6 gene found that the mutation often leads to the premature termination of transcription that in turn results in protein deficiency. Interestingly, both diseases were reported to develop spontaneously in aging mice and humans, and tissues with the highest expression of ABC C6, i.e., kidney and liver, are never affected by this illness, but it is thought that the primary molecular defect occurs in liver metabolism. Thus, the preventive mechanism of ABC C6 on extensive calcification seems to be mediated by systemic rather than tissue-specific factors (79).

ABC C7 ABC C7 is an atypical, evolutionarily young ABC protein, which is the mediator of passive bidirectional diffusion of small inorganic anions and its mutations cause cystic fibrosis [its original name is cystic fibrosis transmembrane regulator (CFTR)] [for review, see (80)]. The malfunction caused by the prevalent deletion of Phe508 in NBD1 prevents conformational maturation of the whole CFTR protein, possibly by disrupting the interaction between NBD1 and NBD2 (81). Its nature makes it a unique intersection of the ion channel and $\mathrm{ABC}$ transporter fields; moreover, it has some special features, e.g., only one of the two NBDs is hydrolytic or its function is regulated by phosphorylation $(82,83)$.

What is extremely interesting from the MDR point of view is that $\mathrm{ABC} \mathrm{C7}$ is able to efflux glutathione conjugates besides its role in transport of salts. Thus, it is able to maintain the basal level of glutathione in lung epithelial lining fluid or increasing this level in reaction to oxidative stress and inflammation, caused by, e.g., cigarette smoke (84). Unexpectedly, elevation in $\mathrm{ABC} \mathrm{C} 7$ expression was observed in patients with breast cancer who had no pathologic evidence of any residual invasive cancer cells in the breast and axillary lymph nodes after paclitaxel/5-fluorouracil, epirubicin, and cyclophosphamide therapy (85). Whether it is a consequence of the treatment or an inherited feature remains to be elucidated.

ABC G2 ABC G2 was initially discovered in multidrug resistant breast cancer cell lines where it conferred resistance to chemotherapeutic agents (BCRP). ABC G2 is highly expressed in normal human tissues exposed to potentially toxic metabolites or environmental substances. Therefore, ABC G2 has been increasingly recognized for its important role in absorption, elimination, and tissue distribution of drugs and xenobiotics. It is able to efflux hydrophobic substrates such as porphyrins, riboflavin, mitoxantrone, estrogens, methotrexate, topotecan, and imatinib, but also hydrophilic conjugated organic anions, particularly the sulfated conjugates. A unique feature is that $\mathrm{ABC} \mathrm{G} 2$ expression in the mammary gland of mice, cows, and humans was found to be strongly induced during lactation, which exposes suckling infants and dairy consumers to xenotoxins (86). At first glance, this seems to be evolutionally disadvantageous, but originally, this could be the way to transfer riboflavin and possibly other essential vitamins (biotin, vitamin K) to infants.

In terms of cancer biology, current research is focusing on the expression and function of ABC G2 in immature stem cells as they contain it in a high abundance (87). During differentiation, the $\mathrm{ABC}$ G2 expression in consecutive progenitors decreases, but in the end, its expression becomes very high again in barrier tissues (e.g., intestine). $A B C G 2$ promoter contains HIF response elements, and thus hypoxia seems to be a potential common feature of stem cells and terminally differentiated cells. However, the high expression of ABC G2 in endothelia disproves this hypothesis. The research is focused mainly on hematopoietic precursors; immature CD34+CD38cells have the highest expression, which declines during 
differentiation to myeloid and lymphoid cells with the exception of erythrocytes and natural killers (88). The importance of ABC G2 in hematopoietic cells might be explained by its ability to confer a strong survival advantage under hypoxic conditions due to efflux of toxic porphyrins that would otherwise accumulate during heme synthesis (89). ABC G2 is also able to inhibit hematopoiesis - a mechanism could be the efflux of differentiation-inducing substrate; its nature has been, however, as yet unknown. This idea is inspired by observation of differentiation of Dictyostelium discoideum amoeba stalk cells by chlorinated polyketide DIF-1, which is inhibited by efflux of DIF-1 by an ABC B1-related transporter (90). Moreover, ABC G2 inhibition also impaired migration and tube formation of endothelial cells (91).

ABC G2 was also described as a uric acid transporter; increased level of uric acid in the blood is the main cause of gout and dysfunctional ABC G2, thus increasing the gout risk. The most extensively studied case is the C421A polymorphism (encoding Q141K), which is associated with enhanced protein degradation (92). This polymorphism causes dysfunction of ABC G2, which correlated to different pharmacokinetics of statins or taxanes resulting in different disease progress after therapy with these agents $(93,94)$. However, the lower function of polymorphic $\mathrm{ABC}$ G2 does not predispose to increased cancer risk (95).

\section{Tissues with abundant expression of MDR- associated $A B C$ transporters}

The $\mathrm{ABC}$ transporters are extensively expressed in the barrierlike cells where they can function as sentinels but concurrently also control the distribution of nutrients; the most important of them are blood-brain and blood-testis barriers, placenta, intestine, liver, kidney, and lung. This dual role is facilitated by polarization of cell membranes via expressing different sets of $\mathrm{ABC}$ transporters on the membrane parts facing the lumen of vessel (luminal/apical part) and surrounding tissue (abluminal/basolateral part), respectively. Summarization of known areas of expression of the above-described $\mathrm{ABC}$ transporters revealed a uniform pattern in their distribution in cytoplasmic membrane. With the only exception of $\mathrm{ABC}$ C4 that has a tissue-specific localization, proteins $\mathrm{ABC} B 1, \mathrm{C} 2$, $\mathrm{C} 5, \mathrm{C} 7$, and $\mathrm{ABC} \mathrm{G} 2$ are found in apical/luminal part of cell membranes and $\mathrm{ABC} \mathrm{C1}, \mathrm{C} 3$, and $\mathrm{C} 6$ in basolateral/abluminal part (Table 1). Description of particular barriers and their specific features follows.

The function of blood-brain barrier epithelial cells is modulated after birth by formation of a sheath of glial cells (mainly astrocytes), which induces a rapid increase of expression of ABC transporters in epithelial cells (96). The second brain barrier, i.e., blood-cerebrospinal fluid barrier is formed by the epithelium of the choroid plexus. Besides the transporters described above and in Table 1, ABC A1 is highly studied as it plays an important role in the prevention of cholesterol uptake in the brain and also in the accumulation of amyloid- $\beta$ (97). However, the mechanism becomes more complex as it was described that amyloid- $\beta$ may serve as a signaling molecule, which inhibits the expression of the $\mathrm{ABC}$ A1 in cultured astrocytes (98).

The defense barrier of the intestine consists mainly of cubic cells of resorbing epithelia, which are rich for many of $A B C$ transporters that are expressed in specific gradients. $\mathrm{ABC} B 1$ expression gradually increases from the stomach to the colon (99). Its expression is the lowest at birth but then it increases (100). Other two apically expressed proteins $A B C$ $\mathrm{G} 2$ and $\mathrm{ABC} C 2$ are the most abundant in the duodenum and less toward the rectum $(101,102)$. Specific expression pattern exhibits the basolateral $\mathrm{ABC} \mathrm{C} 3$ protein as it is the highest in the duodenum and colon and decreases in the small intestine.

Hepatocytes are at a high-risk because of the exposure to the bile acid and metabolites in the blood; therefore, apical transporters excrete metabolites to bile and defend the cells from the bile acids, and basolateral ones efflux back to blood. Besides proteins in Table 1, ABC B4 floppase is important for the proper function of hepatocytes. It translocates phosphatidylcholine to the bile. Mutations in $A B C B 4$ thus cause a spectrum of cholestatic diseases (103). Further important lipid transporter is heterodimeric ABC G5/G8 that effluxes both plant and animal sterols into the bile and its deficiency results in abnormal level of those sterols in plasma (104).

Kidney cells also handle the distribution of a wide spectrum of metabolites and xenobiotics and are dependent on efficient glomerular filtration barrier and distribution of metabolites by the proximal tubules. $\mathrm{ABC}$ transporters expressed in apical membrane pump out substrates destined for terminal excretion from blood into urine and the ones on the basolateral part are returning nutrition to circulation (105).

Lung ABC transporters could either defend the ciliated epithelial cells of the surface epithelium or ciliated collecting ducts and serous cells of bronchial glands. Besides the MDRassociated $\mathrm{ABC}$ proteins (Table 1), the $\mathrm{ABC} A 3$ is specifically important for development and function of lung tissue as its mutations or polymorphisms are associated with respiratory distress, especially in prematurely born children (106).

The blood-testis barrier is formed by endothelial cells, myoid cells, and Sertoli cells. The barrier is responsible for protecting developing germ cells from xenobiotic exposure and divides the seminiferous epithelium into the basal and the apical compartments. Meiosis I and II, spermiogenesis, and spermiation all take place in a specialized microenvironment in the apical compartment, but spermatogonial renewal and differentiation and cell cycle progression up to the preleptotene spermatocyte stage take place in the basal compartment of the epithelium (107).

The human placenta consists of syncytiotrophoblast and cytotrophoblast layers. The syncytiotrophoblast is a multinucleated polarized epithelial layer which functions not only as a transport barrier, but is also responsible for hormone production. The apical membrane of the syncytiotrophoblast is directly bathed in maternal blood, while the basolateral surface is in contact with either the discontinuous cytotrophoblast layer, with stromal tissue or with fetal blood vessels. $\mathrm{ABC} \mathrm{C} 1$ and $\mathrm{ABC} C 5$ proteins play an important role in the organ functional development considering increase in their expression during trophoblast maturation $(108,109)$. Another highly abundant 
transporter is $\mathrm{ABC} \mathrm{A} 1$ and its expression even increases during pregnancy (110). Interestingly, expression of ABC A1 also increases in hypoxic conditions both experimentally and in early-onset pre-eclamptic placentas, and thus implies that cholesterol metabolism may affect this dangerous disorder (111).

\section{Multidrug resistance}

Resistance of cancer cells to chemotherapy could be either inherited or induced by the treatment. It might be caused by increased activity of detoxifying enzymes or DNA-repair mechanisms, by changes of the drug-binding site or by evading the programed cell death. Nevertheless, the major cause is usually the increased expression of $\mathrm{ABC}$ transporters (112). The inherited mechanisms that lead to overexpressed $\mathrm{ABC}$ transporters involve karyotype rearrangements that either duplicate the genes or put them under the influence of strong promoter or enhancer (113). Some gene or promoter mutations can even create the isoform with increased function [reviewed in (114)]. The high ability to efflux drugs could also be inherited from the tumor stem cells as the lessdifferentiated cells are usually rich for $\mathrm{ABC}$ transports (especially ABC G2) (115). The increased level of ABC transporter transcription can be further induced by deregulated kinome via the stress- or hypoxia-related pathways (116). The stress signals are usually triggered by the chemotherapeutics themselves; the hypoxia is caused by insufficient supply of oxygen in the tumor niche [reviewed in (117)].

Strategies to overcome the ABC-associated MDR were first based on pharmacologic inhibitors. The inhibitors of $\mathrm{ABC}$ transporters are often non-metabolizable substrates but their side effects are often as much deleterious than the beneficial effect on down-regulation of $\mathrm{ABC}$ transporters expression (for details see [118]). This way of therapy, however, still leads to the designing of new, more specific generations of drugs.

The more advanced therapeutic strategies are based on knowledge of the molecular basis of the MDR. RNA interference experiments showed that ABC B1-associated MDR could be overcome by transient siRNA-mediated silencing or stable shRNA transfection (119). DNA targeted phosphorothioate oligonucleotides are the first generation of antisense molecules. They are resistant to nucleases, but the clinical use is limited as they could exhibit pharmacological effects unrelated to the antisense effects. They are delivered by lipofectamin, or their uptake could be enhanced by cholesterol conjugation (120). Experimentally, ribozymes were also tested; they are RNAs that have intrinsic endoribonucleolytic cleavage capacity and thus can target specific mRNA. The socalled hammerhead ribozymes were designed to target $\mathrm{ABC}$ $\mathrm{B} 1, \mathrm{C} 2$, and $\mathrm{G} 2$, and even the multitarget multiribozyme was designed to cleave all three mRNAs simultaneously (121).

Nanocarriers (liposomes, micelles, nanoemulsions, polymers, quantum dots, gold, iron oxide, and dendrimers), which are a promising new tool of therapy, allow the transport of drug or above-described interfering agents into the cell without recognition by $\mathrm{ABC}$ transporters as they are internalized via non-specific endocytosis. The versatility of those platforms allows the engineering of multifunctional nanoparticles to make the drug or RNA/DNA delivery more efficient together with active targeting, decreased clearance, and tracking of these vectors. The efficiency of this system was demonstrated in resistant leukemia cells treated with transferring-targeted liposomes loaded with doxorubicin and verapamil (122).

The nanoparticle strategy could also be combined with physical anticancer therapies. Nanoparticles could be loaded with super paramagnetic iron oxide and injected into tumor; the local hyperthermia is thus induced in magnetic field. Temperatures between $40^{\circ} \mathrm{C}$ and $45^{\circ} \mathrm{C}$ then initiate the programed cell death via multiple signals (e.g., deregulation of cell cycle and DNA repair) (123). Another combination is drug-loaded nanoparticles and ultrasound focusing to control drug release, which in in vitro experiments resulted in overcoming MDR (124). When nanoparticles contain photosensitizers (e.g., derivative of hematoporphyrin Photofrin 2), they could also increase the efficiency of photodynamic therapy. The most tumor-specific targeting could be achieved by additional binding of monoclonal antibodies or specific tumor-seeking molecules (125).

\section{Expert opinion}

The attention of researchers in the field of transmembrane transport shifted through the last century from the proteins that allow the survival of cells in a hypertonic environment to the transporters that support the survival of cancer cells making it resistant to the therapy. The ability to confer MDR brought the $\mathrm{ABC}$ transporters under the spotlight. The majority of information regarding principles of efflux, regulation of expression of $\mathrm{ABC}$ transporters, and its correlation with disease progression thus comes from studies performed on MDR-associated ABC transporters. Recently, the previously marginal issues of physiological role of $\mathrm{ABC}$ transporters come to the focus to teach us lessons given by particular MDR-associated protein in healthy homeostatic organisms. The pathways controlling the balanced, beneficial level of potentially deleterious proteins are of common interest as they represent the prospective target of anticancer therapies.

\section{Outlook}

One of the major steps was accomplished by resolving the crystallographic structure of classical mammalian ABC protein. This breakthrough was supposed to be followed by revealing the precise molecular mechanism that drives the efflux of particular substrates. However, difficulties in obtaining the structures of protein in different stages of the transport cycle still hinder the progress even though bacterial models are of much use. The most critical question stays: how is the communication maintained between NBDs and TMDs and what are the mechanisms of spreading and synchronization of signals? The knowledge of the precise mechanism could then help to find the means on how to prevent the onset of MDR in cancer cells. The most efficient way on how to deal with MDR would be the prevention of the overexpression of $\mathrm{ABC}$ 
transporters induced by chemotherapeutics in the beginning of therapy as the strategies based on pharmacologic inhibition of already overexpressed ABC transporters are not much successful $(126,127)$. However, until we find the way how to precede the MDR, nanocarriers are the most promising tool that offers a platform for drug delivery. Nanocarriers can be optimized to overcome biological barriers and customized to achieve diverse treatment strategies that address the complexities of MDR cancer cells (117).

\section{Highlights}

- Functional ABC transporters consist of two TMDs and two ATP-binding domains that contain specific motifs Walker A, B and signature motif.

- A substrate having an appropriate number of electron-donor groups on its hydrophobic backbone binds to the highaffinity pocket in TMDs and the energy from hydrolyzed ATP shifts it to the low-affinity state and thus allows its efflux.

- Expression of ABC transporters is regulated on multiple levels - by proximal promoter and distal enhancing sequences, epigenetically, by stabilization of mRNA, glycosylation, and trafficking of translated product toward the membrane.

- $\mathrm{ABC}$ transporters are highly expressed on barrier-like tissues where they have both secretory and sentinel functions and their membrane localization has the common pattern.

- $\mathrm{ABC}$ genes are highly polymorphic and isoforms could have different pharmacokinetics, but correlations with diseases or diagnostic prognosis is found only rarely.

\section{Acknowledgements}

This manuscript was supported by grant MUNI/A/0975/2009.

\section{References}

1. Krogh A. The active and passive exchanges of inorganic ions through the surfaces of living cells and through living membranes generally. Proc R Soc Med 1946; 133: 140-200.

2. Skou JC. The influence of some cations on an adenosine triphosphatase from peripheral nerves. Biochim Biophys Acta 1957; 23 : 394-401.

3. Keller H, Blennemann H. [Model of active transport power with enzymatic distribution of energy transformation from ATP]. Hoppe-Seyler's Z Physiol Chem 1961; 324: 138-46.

4. Serrano R. Energy requirements for maltose transport in yeast. Eur J Biochem 1977; 80: 97-102.

5. Higgins CF, Hiles ID, Salmond GP, Gill DR, Downie JA, Evans IJ, Holland IB, Gray L, Buckel SD, Bell AW, Hermodson MA. A family of related ATP-binding subunits coupled to many distinct biological processes in bacteria. Nature 1986; 323: 448-50.

6. Hyde SC, Emsley P, Hartshorn MJ, Mimmack MM, Gileadi U, Pearce SR, Gallagher MP, Gill DR, Hubbard RE, Higgins CF.
Structural model of ATP-binding proteins associated with cystic fibrosis, multidrug resistance and bacterial transport. Nature 1990; 346: 362-5.

7. Roninson IB. Molecular mechanism of multidrug resistance in tumor cells. Clin Physiol Biochem 1987; 5: 140-51.

8. Gottesman MM, Ling V. The molecular basis of multidrug resistance in cancer: the early years of P-glycoprotein research. FEBS Lett 2006; 580: 998-1009.

9. Dean M, Rzhetsky A, Allikmets R. The human ATP-binding cassette (ABC) transporter superfamily. Genome Res 2001; 11 : 1156-66.

10. Lodish H, Berk A, Zipursky SL, Matsudaira P, Baltimore D, Darnell J. Molecular cell biology, 4th ed., New York: W.H. Freeman, 2000. ISBN-10: 0-7167-3136-3.

11. Jones PM, O'Mara ML, George AM. ABC transporters: a riddle wrapped in a mystery inside an enigma. Trends Biochem Sci 2009; 34: 520-31.

12. Dey S, Ramachandra M, Pastan I, Gottesman MM, Ambudkar SV. Evidence for two nonidentical drug-interaction sites in the human P-glycoprotein. Proc Natl Acad Sci USA 1997; 94: 10594-9.

13. El-Sheikh AA, van den Heuvel JJ, Krieger E, Russel FG, Koenderink JB. Functional role of arginine 375 in transmembrane helix 6 of multidrug resistance protein 4 (MRP4/ABCC4). Mol Pharmacol 2008; 74: 964-71.

14. Ravna AW, Sylte I, Sager G. Molecular model of the outward facing state of the human P-glycoprotein (ABCB1), and comparison to a model of the human MRP5 (ABCC5). Theor Biol Med Model 2007; 4: 33.

15. Hazai E, Bikádi Z. Homology modeling of breast cancer resistance protein (ABCG2). J Struct Biol 2008; 162: 63-74.

16. Campbell JD, Koike K, Moreau C, Sansom MS, Deeley RG, Cole SP. Molecular modeling correctly predicts the functional importance of Phe594 in transmembrane helix 11 of the multidrug resistance protein, MRP1 (ABCC1). J Biol Chem 2004; 279: 463-8.

17. Williamson G, Aeberli I, Miguet L, Zhang Z, Sanchez MB, Crespy V, Barron D, Needs P, Kroon PA, Glavinas H, Krajcsi $\mathrm{P}$, Grigorov M. Interaction of positional isomers of quercetin glucuronides with the transporter ABCC2 (cMOAT, MRP2). Drug Metab Dispos 2007; 35: 1262-8.

18. Fukushima-Uesaka H, Saito Y, Maekawa K, Hasegawa R, Suzuki K, Yanagawa T, Kajio H, Kuzuya N, Noda M, Yasuda K, Tohkin M, Sawada J. Genetic variations of the ABC transporter gene ABCC3 in a Japanese population. Drug Metab Pharmacokinet 2007; 22: 129-35.

19. Kool M, van der Linden M, de Haas M, Baas F, Borst P. Expression of human MRP6, a homologue of the multidrug resistance protein gene MRP1, in tissues and cancer cells. Cancer Res 1999; 59: 175-82.

20. Lewis HA, Buchanan SG, Burley SK, Conners K, Dickey M, Dorwart M, Fowler R, Gao X, Guggino WB, Hendrickson WA, Hunt JF, Kearins MC, Lorimer D, Maloney PC, Post KW, Rajashankar KR, Rutter ME, Sauder JM, Shriver S, Thibodeau PH, Thomas PJ, Zhang M, Zhao X, Emtage S. Structure of nucleotide-binding domain 1 of the cystic fibrosis transmembrane conductance regulator. EMBO J 2004; 23: 282-93.

21. Moitra K, Scally M, McGee K, Lancaster G, Gold B, Dean M. Molecular evolutionary analysis of ABCB5: the ancestral gene is a full transporter with potentially deleterious single nucleotide polymorphisms. PLoS One 2011; 6: e16318.

22. Yatsenko AN, Wiszniewski W, Zaremba CM, Jamrich M, Lupski JR. Evolution of ABCA4 proteins in vertebrates. J Mol Evol 2005; 60: 72-80. 
23. Gottesman MM, Hrycyna CA, Schoenlein PV, Germann UA, Pastan I. Genetic analysis of the multidrug transporter. Annu Rev Genet 1995; 29: 607-49.

24. Schinkel AH. Pharmacological insights from P-glycoprotein knockout mice. Int J Clin Pharmacol Ther 1998; 36: 9-13.

25. Pondarré C, Antiochos BB, Campagna DR, Clarke SL, Greer EL, Deck KM, McDonald A, Han AP, Medlock A, Kutok JL, Anderson SA, Eisenstein RS, Fleming MD. The mitochondrial ATP-binding cassette transporter Abcb7 is essential in mice and participates in cytosolic iron-sulfur cluster biogenesis. Hum Mol Genet 2006; 15: 953-64.

26. Hammel M, Michel G, Hoefer C, Klaften M, Müller-Höcker J, de Angelis MH, Holzinger A. Targeted inactivation of the murine Abca3 gene leads to respiratory failure in newborns with defective lamellar bodies. Biochem Biophys Res Commun 2007; 359: 947-51.

27. Yanagi T, Akiyama M, Nishihara H, Sakai K, Nishie W, Tanaka $\mathrm{S}$, Shimizu H. Harlequin ichthyosis model mouse reveals alveolar collapse and severe fetal skin barrier defects. Hum Mol Genet 2008; 17: 3075-83.

28. Chutkow WA, Pu J, Wheeler MT, Wada T, Makielski JC, Burant CF, McNally EM. Episodic coronary artery vasospasm and hypertension develop in the absence of Sur2 K(ATP) channels. J Clin Invest 2002; 110: 203-8.

29. Senior AE, al-Shawi MK, Urbatsch IL. The catalytic cycle of P-glycoprotein. FEBS Lett 1995; 377: 285-9.

30. Ambudkar SV, Kim IW, Sauna ZE. The power of the pump: mechanisms of action of P-glycoprotein (ABCB1). Eur J Pharm Sci 2006; 27: 392-400.

31. Seelig A. A general pattern for substrate recognition by P-glycoprotein. Eur J Biochem 1998; 251: 252-61.

32. Locher KP, Lee AT, Rees DC. The E. coli BtuCD structure: a framework for $\mathrm{ABC}$ transporter architecture and mechanism. Science 2002; 296: 1091-8.

33. Scotto KW. Transcriptional regulation of ABC drug transporters. Oncogene 2003; 22: 7496-511.

34. Sukhai M, Piquette-Miller M. Regulation of the multidrug resistance genes by stress signals. J Pharm Pharm Sci 2000; 3: 268-80.

35. Cripe LD, Gelfanov VM, Smith EA, Spigel DR, Phillips CA, Gabig TG, Jung SH, Fyffe J, Hartman AD, Kneebone P, Mercola D, Burgess GS, Boswell HS. Role for c-jun N-terminal kinase in treatment-refractory acute myeloid leukemia (AML): signaling to multidrug-efflux and hyperproliferation. Leukemia 2002; 16 : 799-812.

36. Chaudhary PM, Roninson IB. Induction of multidrug resistance in human cells by transient exposure to different chemotherapeutic drugs. J Natl Cancer Inst 1993; 85: 632-9.

37. Kohno K, Sato S, Takano H, Matsuo K, Kuwano M. The direct activation of human multidrug resistance gene (MDR1) by anticancer agents. Biochem Biophys Res Commun 1989; 165: $1415-21$.

38. Hu Z, Jin S, Scotto KW. Transcriptional activation of the MDR1 gene by UV irradiation. Role of NF-Y and Sp1. J Biol Chem 2000; 275: 2979-85.

39. Randle RA, Raguz S, Higgins CF, Yagüe E. Role of the highly structured $5^{\prime}$-end region of MDR1 mRNA in P-glycoprotein expression. Biochem J 2007; 406: 445-55.

40. Tazzari PL, Cappellini A, Ricci F, Evangelisti C, Papa V, Grafone T, Martinelli G, Conte R, Cocco L, McCubrey JA, Martelli AM. Multidrug resistance-associated protein 1 expression is under the control of the phosphoinositide 3 kinase/Akt signal transduction network in human acute myelogenous leukemia blasts. Leukemia 2007; 21: 427-38.
41. Mogi M, Yang J, Lambert JF, Colvin GA, Shiojima I, Skurk C, Summer R, Fine A, Quesenberry PJ, Walsh K. Akt signaling regulates side population cell phenotype via Bcrp1 translocation. J Biol Chem 2003; 278: 39068-75.

42. Takada T, Suzuki H, Gotoh Y, Sugiyama Y. Regulation of the cell surface expression of human BCRP/ABCG2 by the phosphorylation state of Akt in polarized cells. Drug Metab Dispos 2005; 33 : 905-9.

43. Sugiyama T, Shuto T, Suzuki S, Sato T, Koga T, Suico MA, Kusuhara H, Sugiyama Y, Cyr DM, Kai H. Posttranslational negative regulation of glycosylated and non-glycosylated BCRP expression by Derlin-1. Biochem Biophys Res Commun 2011; 404: 853-8.

44. Knop M, Finger A, Braun T, Hellmuth K, Wolf DH. Der1, a novel protein specifically required for endoplasmic reticulum degradation in yeast. EMBO J 1996; 15: 753-63.

45. Wakabayashi-Nakao K, Tamura A, Furukawa T, Nakagawa H, Ishikawa T. Quality control of human ABCG2 protein in the endoplasmic reticulum: ubiquitination and proteasomal degradation. Adv Drug Deliv Rev 2009; 61: 66-72.

46. Draheim V, Reichel A, Weitschies W, Moenning U. $\mathrm{N}$-glycosylation of $\mathrm{ABC}$ transporters is associated with functional activity in sandwich-cultured rat hepatocytes. Eur J Pharm Sci 2010; 41: 201-9.

47. Eckford PD, Sharom FJ. Interaction of the P-glycoprotein multidrug efflux pump with cholesterol: effects on ATPase activity, drug binding and transport. Biochemistry 2008; 47 : 13686-98.

48. Li YH, Wang YH, Li Y, Yang L. MDR1 gene polymorphisms and clinical relevance. Yi Chuan Xue Bao 2006; 33: 93-104.

49. Kimchi-Sarfaty C, Oh JM, Kim IW, Sauna ZE, Calcagno AM, Ambudkar SV, Gottesman MM. A 'silent' polymorphism in the MDR1 gene changes substrate specificity. Science 2007; 315 : $525-8$.

50. Yi SY, Hong KS, Lim HS, Chung JY, Oh DS, Kim JR, Jung HR, Cho JY, Yu KS, Jang IJ, Shin SG. A variant 2677A allele of the MDR1 gene affects fexofenadine disposition. Clin Pharmacol Ther 2004; 76: 418-27.

51. Tanabe M, Ieiri I, Nagata N, Inoue K, Ito S, Kanamori Y, Takahashi M, Kurata Y, Kigawa J, Higuchi S, Terakawa N, Otsubo K. Expression of P-glycoprotein in human placenta: relation to genetic polymorphism of the multidrug resistance (MDR)-1 gene. J Pharmacol Exp Ther 2001; 297: 1137-43.

52. Zheng H, Webber S, Zeevi A, Schuetz E, Zhang J, Lamba J, Bowman P, Burckart GJ. The MDR1 polymorphisms at exons 21 and 26 predict steroid weaning in pediatric heart transplant patients. Hum Immunol 2002; 63: 765-70.

53. Asano T, Takahashi KA, Fujioka M, Inoue S, Okamoto M, Sugioka N, Nishino H, Tanaka T, Hirota Y, Kubo T. ABCB1 C3435T and G2677T/A polymorphism decreased the risk for steroid-induced osteonecrosis of the femoral head after kidney transplantation. Pharmacogenetics 2003; 13: 675-82.

54. Hamidovic A, Hahn K, Kolesar J. Clinical significance of ABCB1 genotyping in oncology. J Oncol Pharm Pract 2010; 16: 39-44.

55. Kohen R, Shofer JB, Korvatska O, Petrie EC, Wang LY, Schellenberg GD, Peskind ER, Wilkinson CW. ABCB1 genotype and CSF $\beta$-amyloid in Alzheimer's disease. J Geriatr Psychiatry Neurol 2011; 24: 63-6.

56. Furuno T, Landi MT, Ceroni M, Caporaso N, Bernucci I, Nappi G, Martignoni E, Schaeffeler E, Eichelbaum M, Schwab M, Zanger UM. Expression polymorphism of the blood-brain barrier component P-glycoprotein (MDR1) in relation to Parkinson's disease. Pharmacogenetics 2002; 12: 529-34. 
57. Toyoda Y, Hagiya Y, Adachi T, Hoshijima K, Kuo MT, Ishikawa T. MRP class of human ATP binding cassette $(\mathrm{ABC})$ transporters: historical background and new research directions. Xenobiotica 2008; 38: 833-62.

58. Wanke D, Kolukisaoglu HU. An update on the ABCC transporter family in plants: many genes, many proteins, but how many functions? Plant Biol (Stuttg) 2010; 12(Suppl 1): 15-25.

59. Robbiani DF, Finch RA, Jager D, Muller WA, Sartorelli AC, Randolph GJ. The leukotriene C(4) transporter MRP1 regulates CCL19 (MIP-3ß, ELC)-dependent mobilization of dendritic cells to lymph nodes. Cell 2000; 103: 757-68.

60. Yoshioka M, Sagara H, Takahashi F, Harada N, Nishio K, Mori A, Ushio H, Shimizu K, Okada T, Ota M, Ito YM, Nagashima O, Atsuta R, Suzuki T, Fukuda T, Fukuchi Y, Takahashi K. Role of multidrug resistance-associated protein 1 in the pathogenesis of allergic airway inflammation. Am J Physiol Lung Cell Mol Physiol 2009; 296: L30-6.

61. van de Ven R, de Jong MC, Reurs AW, Schoonderwoerd AJ, Jansen G, Hooijberg JH, Scheffer GL, de Gruijl TD, Scheper RJ. Dendritic cells require multidrug resistance protein 1 (ABCC1) transporter activity for differentiation. J Immunol 2006; 176: 5191-8.

62. Keppler D, Konig J. Hepatic canalicular membrane 5: Expression and localization of the conjugate export pump encoded by the MRP2 (cMRP/cMOAT) gene in liver. FASEB J 1997; 11: 509-16.

63. Maciejczyk A, Jagoda E, Wysocka T, Matkowski R, Gyorffy B, Lage H, Surowiak P. ABCC2 (MRP2, cMOAT) Localized in the nuclear envelope of breast carcinoma cells correlates with poor clinical outcome. Pathol Oncol Res 2012; 18: 331-42.

64. O’Brien C, Cavet G, Pandita A, Hu X, Haydu L, Mohan S, Toy K, Rivers CS, Modrusan Z, Amler LC, Lackner MR. Functional genomics identifies $\mathrm{ABCC} 3$ as a mediator of taxane resistance in HER2-amplified breast cancer. Cancer Res 2008; 68: 5380-9.

65. Chen ZS, Lee K, Kruh GD. Transport of cyclic nucleotides and estradiol 17- $\beta$-D-glucuronide by multidrug resistance protein 4 . Resistance to 6-mercaptopurine and 6-thioguanine. J Biol Chem 2001; 276: 33747-54.

66. Touyz RM, Picard S, Schiffrin EL, Deschepper CF. Cyclic GMP inhibits a pharmacologically distinct $\mathrm{Na}+\mathrm{H}+$ exchanger variant in cultured rat astrocytes via an extracellular site of action. $\mathrm{J}$ Neurochem 1997; 68: 1451-61.

67. Roelofsen H, Soroka CJ, Keppler D, Boyer JL. Cyclic AMP stimulates sorting of the canalicular organic anion transporter (Mrp2/ cMoat) to the apical domain in hepatocyte couplets. J Cell Sci 1998; 111(Pt 8): 1137-45.

68. Li C, Krishnamurthy PC, Penmatsa H, Marrs KL, Wang XQ, Zaccolo M, Jalink K, Li M, Nelson DJ, Schuetz JD, Naren AP. Spatiotemporal coupling of cAMP transporter to CFTR chloride channel function in the gut epithelia. Cell 2007; 131: 940-51.

69. Lamba JK, Adachi M, Sun D, Tammur J, Schuetz EG, Allikmets R, Schuetz JD. Nonsense mediated decay downregulates conserved alternatively spliced ABCC4 transcripts bearing nonsense codons. Hum Mol Genet 2003; 12: 99-109.

70. Oevermann L, Scheitz J, Starke K, Köck K, Kiefer T, Dölken G, Niessen J, Greinacher A, Siegmund W, Zygmunt M, Kroemer HK, Jedlitschky G, Ritter CA. Hematopoietic stem cell differentiation affects expression and function of MRP4 (ABCC4), a transport protein for signaling molecules and drugs. Int $\mathrm{J}$ Cancer 2009; 124: 2303-11.

71. Jedlitschky G, Cattaneo M, Lubenow LE, Rosskopf D, Lecchi A, Artoni A, Motta G, Niessen J, Kroemer HK, Greinacher A.
Role of MRP4 (ABCC4) in platelet adenine nucleotide-storage: evidence from patients with $\delta$-storage pool deficiencies. Am J Pathol 2010; 176: 1097-103.

72. Ansari M, Sauty G, Labuda M, Gagne V, Laverdiere C, Moghrabi A, Sinnett D, Krajinovic M. Polymorphisms in multidrug resistance-associated protein gene 4 is associated with outcome in childhood acute lymphoblastic leukemia. Blood 2009; 114: 1383-6.

73. Scaglione F, Berrino L. Cytosine deoxyribonucleoside anti-HIV analogues: a small chemical substitution allows relevant activities. Int J Antimicrob Agents 2012. [Epub ahead of print].

74. Anderson PL, Lamba J, Aquilante CL, Schuetz E, Fletcher CV. Pharmacogenetic characteristics of indinavir, zidovudine, and lamivudine therapy in HIV-infected adults: a pilot study. J Acquir Immune Defic Syndr 2006; 42: 441-9.

75. Sampath J, Adachi M, Hatse S, Naesens L, Balzarini J, Flatley RM, Matherly LH, Schuetz JD. Role of MRP4 and MRP5 in biology and chemotherapy. AAPS PharmSci 2002; 4: E14.

76. Dazert P, Meissner K, Vogelgesang S, Heydrich B, Eckel L, Bohm M, Warzok R, Kerb R, Brinkmann U, Schaeffeler E, Schwab M, Cascorbi I, Jedlitschky G, Kroemer HK. Expression and localization of the multidrug resistance protein 5 (MRP5/ABCC5), a cellular export pump for cyclic nucleotides, in human heart. Am J Pathol 2003; 163: 1567-77.

77. Knauer MJ, Urquhart BL, Meyer zu Schwabedissen HE, Schwarz UI, Lemke CJ, Leake BF, Kim RB, Tirona RG. Human skeletal muscle drug transporters determine local exposure and toxicity of statins. Circ Res 2010; 106: 297-306.

78. Uitto J, Bercovitch L, Terry SF, Terry PF. Pseudoxanthoma elasticum: progress in diagnostics and research towards treatment. Summary of the 2010 PXE International Research Meeting. Am J Med Genet, Part A 2011; 155A: 1517-26.

79. Aherrahrou Z, Doehring LC, Ehlers EM, Liptau H, Depping R, Linsel-Nitschke P, Kaczmarek PM, Erdmann J, Schunkert H. An alternative splice variant in Abcc6, the gene causing dystrophic calcification, leads to protein deficiency in $\mathrm{C} 3 \mathrm{H} / \mathrm{He}$ mice. J Biol Chem 2008; 283: 7608-15.

80. Aleksandrov AA, Aleksandrov LA, Riordan JR. CFTR (ABCC7) is a hydrolyzable-ligand-gated channel. Pflugers Arch 2007; 453: 693-702.

81. Cui L, Aleksandrov L, Chang XB, Hou YX, He L, Hegedus T, Gentzsch M, Aleksandrov A, Balch WE, Riordan JR. Domain interdependence in the biosynthetic assembly of CFTR. J Mol Biol 2007; 365: 981-94.

82. Aleksandrov L, Aleksandrov AA, Chang XB, Riordan JR. The first nucleotide binding domain of cystic fibrosis transmembrane conductance regulator is a site of stable nucleotide interaction, whereas the second is a site of rapid turnover. J Biol Chem 2002; 277: 15419-25.

83. Liang X, Da Paula AC, Bozóky Z, Zhang H, Bertrand CA, Peters KW, Forman-Kay JD, Frizzell RA. Phosphorylation-dependent 14-3-3 protein interactions regulate CFTR biogenesis. Mol Biol Cell 2012; 23: 996-1009.

84. Gould NS, Min E, Martin RJ, Day BJ. CFTR is the primary known apical glutathione transporter involved in cigarette smoke-induced adaptive responses in the lung. Free Radic Biol Med 2012; 52: 1201-6.

85. Park S, Shimizu C, Shimoyama T, Takeda M, Ando M, Kohno T, Katsumata N, Kang YK, Nishio K, Fujiwara Y. Gene expression profiling of ATP-binding cassette $(\mathrm{ABC})$ transporters as a predictor of the pathologic response to neoadjuvant chemotherapy in breast cancer patients. Breast Cancer Res Treat 2006; 99: 9-17. 
86. van Herwaarden AE, Schinkel AH. The function of breast cancer resistance protein in epithelial barriers, stem cells and milk secretion of drugs and xenotoxins. Trends Pharmacol Sci 2006; 27: 10-6.

87. Procházková J, Kubala L, Kotasová H, Gudernová I, Šrámková Z, Pekarová M, Sarkadi B, Pacherník J. ABC transporters affect the detection of intracellular oxidants by fluorescent probes. Free Radic Res 2011; 45: 779-87.

88. Scharenberg CW, Harkey MA, Torok-Storb B. The ABCG2 transporter is an efficient Hoechst 33342 efflux pump and is preferentially expressed by immature human hematopoietic progenitors. Blood 2002; 99: 507-12.

89. Krishnamurthy P, Ross DD, Nakanishi T, Bailey-Dell K, Zhou S, Mercer KE, Sarkadi B, Sorrentino BP, Schuetz JD. The stem cell marker Bcrp/ABCG2 enhances hypoxic cell survival through interactions with heme. J Biol Chem 2004; 279: 24218-25.

90. Good JR, Kuspa A. Evidence that a cell-type-specific efflux pump regulates cell differentiation in Dictyostelium. Dev Biol 2000; 220: 53-61.

91. Higashikuni Y, Sainz J, Nakamura K, Takaoka M, Enomoto S, Iwata H, Sahara M, Tanaka K, Koibuchi N, Ito S, Kusuhara H, Sugiyama Y, Hirata Y, Nagai R, Sata M. The ATP-binding cassette transporter BCRP1/ABCG2 plays a pivotal role in cardiac repair after myocardial infarction via modulation of microvascular endothelial cell survival and function. Arterioscler Thromb Vasc Biol 2010; 30: 2128-35.

92. Woodward OM, Köttgen A, Coresh J, Boerwinkle E, Guggino WB, Köttgen M. Identification of a urate transporter, ABCG2, with a common functional polymorphism causing gout. Proc Natl Acad Sci USA 2009; 106: 10338-42.

93. Keskitalo JE, Pasanen MK, Neuvonen PJ, Niemi M. Different effects of the ABCG2 c.421C >A SNP on the pharmacokinetics of fluvastatin, pravastatin and simvastatin. Pharmacogenomics 2009; 10: 1617-24.

94. Tian C, Ambrosone CB, Darcy KM, Krivak TC, Armstrong DK, Bookman MA, Davis W, Zhao H, Moysich K, Gallion H, Deloia JA. Common variants in $\mathrm{ABCB} 1, \mathrm{ABCC} 2$ and $\mathrm{ABCG} 2$ genes and clinical outcomes among women with advanced stage ovarian cancer treated with platinum and taxane-based chemotherapy: a Gynecologic Oncology Group study. Gynecol Oncol 2012; 124: 575-81.

95. Gardner ER, Ahlers CM, Shukla S, Sissung TM, Ockers SB, Price DK, Hamada A, Robey RW, Steinberg SM, Ambudkar SV, Dahut WL, Figg WD. Association of the ABCG2 C421A polymorphism with prostate cancer risk and survival. BJU Int 2008; 102: 1694-9.

96. Daneman R, Zhou L, Kebede AA, Barres BA. Pericytes are required for blood-brain barrier integrity during embryogenesis. Nature 2010; 468: 562-6.

97. Wahrle SE, Jiang H, Parsadanian M, Hartman RE, Bales KR, Paul SM, Holtzman DM. Deletion of Abca1 increases Abeta deposition in the PDAPP transgenic mouse model of Alzheimer disease. J Biol Chem 2005; 280: 43236-42.

98. Canepa E, Borghi R, Vina J, Traverso N, Gambini J, Domenicotti C, Marinari UM, Poli G, Pronzato MA, Ricciarelli R. Cholesterol and amyloid- $\beta$ : evidence for a cross-talk between astrocytes and neuronal cells. J Alzheimers Dis 2011; 25: 645-53.

99. Thörn M, Finnström N, Lundgren S, Rane A, Lööf L. Cytochromes P450 and MDR1 mRNA expression along the human gastrointestinal tract. Br J Clin Pharmacol 2005; 60: $54-60$.

100. Mahmood B, Daood MJ, Hart C, Hansen TW, Watchko JF. Ontogeny of P-glycoprotein in mouse intestine, liver, and kidney. J Investig Med 2001; 49: 250-7.
101. Zimmermann C, Gutmann H, Hruz P, Gutzwiller JP, Beglinger $\mathrm{C}$, Drewe J. Mapping of multidrug resistance gene 1 and multidrug resistance-associated protein isoform 1 to $5 \mathrm{mRNA}$ expression along the human intestinal tract. Drug Metab Dispos 2005; 33: 219-24.

102. Gutmann H, Hruz P, Zimmermann C, Beglinger C, Drewe J. Distribution of breast cancer resistance protein (BCRP/ ABCG2) mRNA expression along the human GI tract. Biochem Pharmacol 2005; 70: 695-9.

103. Groen A, Romero MR, Kunne C, Hoosdally SJ, Dixon PH, Wooding C, Williamson C, Seppen J, Van den Oever K, Mok KS, Paulusma CC, Linton KJ, Oude Elferink RP. Complementary functions of the flippase ATP8B1 and the floppase ABCB4 in maintaining canalicular membrane integrity. Gastroenterology 2011; 141: 1927-37 e1-4.

104. Nicolaou M, Andress EJ, Zolnerciks JK, Dixon PH, Williamson C, Linton KJ. Canalicular ABC transporters and liver disease. J Pathol 2012; 226: 300-15.

105. Schinkel AH, Jonker JW. Mammalian drug efflux transporters of the ATP binding cassette (ABC) family: an overview. Adv Drug Deliv Rev 2003; 55: 3-29.

106. Karjalainen MK, Haataja R, Hallman M. Haplotype analysis of ABCA3: association with respiratory distress in very premature infants. Ann Med 2008; 40: 56-65.

107. Cheng CY, Mruk DD. The blood-testis barrier and its implications for male contraception. Pharmacol Rev 2012; 64: $16-64$.

108. Pascolo L, Fernetti C, Pirulli D, Crovella S, Amoroso A, Tiribelli C. Effects of maturation on RNA transcription and protein expression of four MRP genes in human placenta and in BeWo cells. Biochem Biophys Res Commun 2003; 303: 259-65.

109. Meyer Zu Schwabedissen HE, Grube M, Heydrich B, Linnemann K, Fusch C, Kroemer HK, Jedlitschky G. Expression, localization, and function of MRP5 (ABCC5), a transporter for cyclic nucleotides, in human placenta and cultured human trophoblasts: effects of gestational age and cellular differentiation. Am J Pathol 2005; 166: 39-48.

110. Bhattacharjee J, Ietta F, Giacomello E, Bechi N, Romagnoli R, Fava A, Paulesu L. Expression and localization of ATP binding cassette transporter A1 (ABCA1) in first trimester and term human placenta. Placenta 2010; 31: 423-30.

111. Plösch T, Gellhaus A, van Straten EM, Wolf N, Huijkman NC, Schmidt M, Dunk CE, Kuipers F, Winterhager E. The liver X receptor (LXR) and its target gene ABCA1 are regulated upon low oxygen in human trophoblast cells: a reason for alterations in preeclampsia? Placenta 2010; 31: 910-8.

112. Liu FS. Mechanisms of chemotherapeutic drug resistance in cancer therapy - a quick review. Taiwan J Obstet Gynecol 2009; 48: 239-44.

113. Mickley LA, Spengler BA, Knutsen TA, Biedler JL, Fojo T. Gene rearrangement: a novel mechanism for MDR-1 gene activation. J Clin Invest 1997; 99: 1947-57.

114. Frelet A, Klein M. Insight in eukaryotic ABC transporter function by mutation analysis. FEBS Lett 2006; 580: 1064-84.

115. Abbott BL. ABCG2 (BCRP) expression in normal and malignant hematopoietic cells. Hematol Oncol 2003; 21: 115-30.

116. Trédan O, Galmarini CM, Patel K, Tannock IF. Drug resistance and the solid tumor microenvironment. J Natl Cancer Inst 2007; 99: 1441-54.

117. Milane L, Ganesh S, Shah S, Duan ZF, Amiji M. Multi-modal strategies for overcoming tumor drug resistance: hypoxia, the Warburg effect, stem cells, and multifunctional nanotechnology. J Control Release 2011; 155: 237-47. 
118. Ozben T. Mechanisms and strategies to overcome multiple drug resistance in cancer. FEBS Lett 2006; 580: 2903-9.

119. Lage H. Therapeutic potential of RNA interference in drugresistant cancers. Future Oncol 2009; 5: 169-85.

120. Alahari SK, Dean NM, Fisher MH, Delong R, Manoharan M, Tivel KL, Juliano RL. Inhibition of expression of the multidrug resistance-associated P-glycoprotein of by phosphorothioate and $5^{\prime}$ cholesterol-conjugated phosphorothioate antisense oligonucleotides. Mol Pharmacol 1996; 50: 808-19.

121. Kowalski P, Surowiak P, Lage H. Reversal of different drug-resistant phenotypes by an autocatalytic multitarget multiribozyme directed against the transcripts of the $\mathrm{ABC}$ transporters MDR1/P-gp, MRP2, and BCRP. Mol Ther 2005; 11: 508-22.

122. Wu J, Lu Y, Lee A, Pan X, Yang X, Zhao X, Lee RJ. Reversal of multidrug resistance by transferrin-conjugated liposomes coencapsulating doxorubicin and verapamil. J Pharm Pharm Sci 2007; 10: 350-7.

123. Jordan A, Scholz R, Wust P, Fähling H, Felix R. Magnetic fluid hyperthermia $(\mathrm{MFH})$ : cancer treatment with $\mathrm{AC}$ magnetic field induced excitation of biocompatible superparamagnetic nanoparticles. J Magnetism Magnetic Mater 1999; 201: 413-19.

124. Rapoport N. Combined cancer therapy by micellar-encapsulated drug and ultrasound. Int J Pharm 2004; 277: 155-62.

125. Konan YN, Gurny R, Allémann E. State of the art in the delivery of photosensitizers for photodynamic therapy. J Photochem Photobiol B 2002; 66: 89-106.

126. Abolhoda A, Wilson AE, Ross H, Danenberg PV, Burt M, Scotto KW. Rapid activation of MDR1 gene expression in human metastatic sarcoma after in vivo exposure to doxorubicin. Clin Cancer Res 1999; 5: 3352-6.

127. Tiwari AK, Sodani K, Dai CL, Ashby CR Jr, Chen ZS. Revisiting the $\mathrm{ABCs}$ of multidrug resistance in cancer chemotherapy. Curr Pharm Biotechnol 2011; 12: 570-94.

128. Urquhart BL, Kim RB. Blood-brain barrier transporters and response to CNS-active drugs. Eur J Clin Pharmacol 2009; 65: 1063-70.

129. Bauer B, Hartz AM, Lucking JR, Yang X, Pollack GM, Miller DS. Coordinated nuclear receptor regulation of the efflux transporter, Mrp2, and the phase-II metabolizing enzyme, GSTpi, at the blood-brain barrier. J Cereb Blood Flow Metab 2008; 28: 1222-34.

130. Zhang Y, Schuetz JD, Elmquist WF, Miller DW. Plasma membrane localization of multidrug resistance-associated protein homologs in brain capillary endothelial cells. J Pharmacol Exp Ther 2004; 311: 449-55.

131. Gazzin S, Berengeno AL, Strazielle N, Fazzari F, Raseni A, Ostrow JD, Wennberg R, Ghersi-Egea JF, Tiribelli C. Modulation of Mrp1 (ABCc1) and Pgp (ABCb1) by bilirubin at the blood-CSF and blood-brain barriers in the Gunn rat. PLoS One 2011; 6: e16165.

132. Zhang Y, Han H, Elmquist WF, Miller DW. Expression of various multidrug resistance-associated protein (MRP) homologues in brain microvessel endothelial cells. Brain Res 2000; 876: 148-53.

133. Lechapt-Zalcman E, Hurbain I, Lacave R, Commo F, Urban T, Antoine M, Milleron B, Bernaudin JF. MDR1-Pgp 170 expression in human bronchus. Eur Respir J 1997; 10: 1837-43.

134. Tagami M, Kusuhara S, Honda S, Tsukahara Y, Negi A. Expression of ATP-binding cassette transporters at the inner blood-retinal barrier in a neonatal mouse model of oxygeninduced retinopathy. Brain Res 2009; 1283: 186-93.
135. Weksler BB, Subileau EA, Perrière N, Charneau P, Holloway K, Leveque M, Tricoire-Leignel H, Nicotra A, Bourdoulous S, Turowski P, Male DK, Roux F, Greenwood J, Romero IA, Couraud PO. Blood-brain barrier-specific properties of a human adult brain endothelial cell line. FASEB J 2005; 19: 1872-4.

136. Tousson A, Van Tine BA, Naren AP, Shaw GM, Schwiebert LM. Characterization of CFTR expression and chloride channel activity in human endothelia. Am J Physiol 1998; 275: C1555-64.

137. Asashima T, Hori S, Ohtsuki S, Tachikawa M, Watanabe M, Mukai C, Kitagaki S, Miyakoshi N, Terasaki T. ATP-binding cassette transporter G2 mediates the efflux of phototoxins on the luminal membrane of retinal capillary endothelial cells. Pharm Res 2006; 23: 1235-42.

138. Eilers M, Roy U, Mondal D. MRP (ABCC) transportersmediated efflux of anti-HIV drugs, saquinavir and zidovudine, from human endothelial cells. Exp Biol Med (Maywood) 2008; 233: 1149-60.

139. Warren MS, Zerangue N, Woodford K, Roberts LM, Tate EH, Feng B, Li C, Feuerstein TJ, Gibbs J, Smith B, de Morais SM, Dower WJ, Koller KJ. Comparative gene expression profiles of $\mathrm{ABC}$ transporters in brain microvessel endothelial cells and brain in five species including human. Pharmacol Res 2009; 59: 404-13.

140. Beck K, Hayashi K, Nishiguchi B, Le Saux O, Hayashi M, Boyd $\mathrm{CD}$. The distribution of Abcc6 in normal mouse tissues suggests multiple functions for this $\mathrm{ABC}$ transporter. J Histochem Cytochem 2003; 51: 887-902.

141. Wioland MA, Fleury-Feith J, Corlieu P, Commo F, Monceaux G, Lacau-St-Guily J, Bernaudin JF. CFTR, MDR1, and MRP1 immunolocalization in normal human nasal respiratory mucosa. J Histochem Cytochem 2000; 48: 1215-22.

142. Sandusky GE, Mintze KS, Pratt SE, Dantzig AH. Expression of multidrug resistance-associated protein 2 (MRP2) in normal human tissues and carcinomas using tissue microarrays. Histopathology 2002; 41: 65-74.

143. Scheffer GL, Kool M, de Haas M, de Vree JM, Pijnenborg AC, Bosman DK, Elferink RP, van der Valk P, Borst P, Scheper RJ. Tissue distribution and induction of human multidrug resistant protein 3. Lab Invest 2002; 82: 193-201.

144. van de Wetering K, Zelcer N, Kuil A, Feddema W, Hillebrand M, Vlaming ML, Schinkel AH, Beijnen JH, Borst P. Multidrug resistance proteins 2 and 3 provide alternative routes for hepatic excretion of morphine-glucuronides. Mol Pharmacol 2007; 72: 387-94.

145. Kinnman N, Lindblad A, Housset C, Buentke E, Scheynius A, Strandvik B, Hultcrantz R. Expression of cystic fibrosis transmembrane conductance regulator in liver tissue from patients with cystic fibrosis. Hepatology 2000; 32: 334-40.

146. Maliepaard M, Scheffer GL, Faneyte IF, van Gastelen MA, Pijnenborg AC, Schinkel AH, van De Vijver MJ, Scheper RJ, Schellens JH. Subcellular localization and distribution of the breast cancer resistance protein transporter in normal human tissues. Cancer Res 2001; 61: 3458-64.

147. Jonker JW, Smit JW, Brinkhuis RF, Maliepaard M, Beijnen JH, Schellens JH, Schinkel AH. Role of breast cancer resistance protein in the bioavailability and fetal penetration of topotecan. J Natl Cancer Inst 2000; 92: 1651-6.

148. Mayer R, Kartenbeck J, Buchler M, Jedlitschky G, Leier I, Keppler D. Expression of the MRP gene-encoded conjugate export pump in liver and its selective absence from the canalicular membrane in transport-deficient mutant hepatocytes. J Cell Biol 1995; 131: 137-50. 
149. Rius M, Nies AT, Hummel-Eisenbeiss J, Jedlitschky G, Keppler D. Cotransport of reduced glutathione with bile salts by MRP4 (ABCC4) localized to the basolateral hepatocyte membrane. Hepatology 2003; 38: 374-84.

150. Denk GU, Soroka CJ, Takeyama Y, Chen WS, Schuetz JD, Boyer JL. Multidrug resistance-associated protein 4 is upregulated in liver but down-regulated in kidney in obstructive cholestasis in the rat. J Hepatol 2004; 40: 585-91.

151. Madon J, Hagenbuch B, Landmann L, Meier PJ, Stieger B. Transport function and hepatocellular localization of mrp6 in rat liver. Mol Pharmacol 2000; 57: 634-41.

152. van Aubel RA, Smeets PH, Peters JG, Bindels RJ, Russel FG. The MRP4/ABCC4 gene encodes a novel apical organic anion transporter in human kidney proximal tubules: putative efflux pump for urinary cAMP and cGMP. J Am Soc Nephrol 2002; 13: 595-603.

153. Morales MM, Falkenstein D, Lopes AG. The cystic fibrosis transmembrane regulator (CFTR) in the kidney. An Acad Bras Cienc 2000; 72: 399-406.

154. Huls M, Russel FG, Masereeuw R. The role of ATP binding cassette transporters in tissue defense and organ regeneration. J Pharmacol Exp Ther 2009; 328: 3-9.

155. Peng KC, Cluzeaud F, Bens M, Duong Van Huyen JP, Wioland MA, Lacave R, Vandewalle A. Tissue and cell distribution of the multidrug resistance-associated protein (MRP) in mouse intestine and kidney. J Histochem Cytochem 1999; 47: 757-68.

156. Rao VV, Dahlheimer JL, Bardgett ME, Snyder AZ, Finch RA, Sartorelli AC, Piwnica-Worms D. Choroid plexus epithelial expression of MDR1 P glycoprotein and multidrug resistanceassociated protein contribute to the blood-cerebrospinal-fluid drug-permeability barrier. Proc Natl Acad Sci USA 1999; 96: 3900-5.

157. Soontornmalai A, Vlaming ML, Fritschy JM. Differential, strain-specific cellular and subcellular distribution of multidrug transporters in murine choroid plexus and blood-brain barrier. Neuroscience 2006; 138: 159-69.

158. Hincke MT, Nairn AC, Staines WA. Cystic fibrosis transmembrane conductance regulator is found within brain ventricular epithelium and choroid plexus. J Neurochem 1995; 64: 1662-8.

159. Cooray HC, Blackmore CG, Maskell L, Barrand MA. Localisation of breast cancer resistance protein in microvessel endothelium of human brain. Neuroreport 2002; 13: 2059-63.
160. Reichel V, Kläs J, Fricker G, Masereeuw R. Fluo-cAMP is transported by multidrug resistance-associated protein isoform 4 in rat choroid plexus. J Neurochem 115: 200-8.

161. Atkinson DE, Greenwood SL, Sibley CP, Glazier JD, Fairbairn LJ. Role of MDR1 and MRP1 in trophoblast cells, elucidated using retroviral gene transfer. Am J Physiol Cell Physiol 2003; 285: C584-91.

162. Nagashige M, Ushigome F, Koyabu N, Hirata K, Kawabuchi M, Hirakawa T, Satoh S, Tsukimori K, Nakano H, Uchiumi T, Kuwano M, Ohtani H, Sawada Y. Basal membrane localization of MRP1 in human placental trophoblast. Placenta 2003; 24: 951-8.

163. St-Pierre MV, Serrano MA, Macias RI, Dubs U, Hoechli M, Lauper U, Meier PJ, Marin JJ. Expression of members of the multidrug resistance protein family in human term placenta. Am J Physiol Regul Integr Comp Physiol 2000; 279: R1495-503.

164. Faller DP, Egan DA, Ryan MP. Evidence for location of the CFTR in human placental apical membrane vesicles. Am J Physiol 1995; 269: C148-55.

165. Damiano AE. Review: water channel proteins in the human placenta and fetal membranes. Placenta 2011; 32(Suppl 2): S207-11.

166. Aleksunes LM, Cui Y, Klaassen CD. Prominent expression of xenobiotic efflux transporters in mouse extraembryonic fetal membranes compared with placenta. Drug Metab Dispos 2008; 36: $1960-70$

167. Robillard KR, Hoque MT, Bendayan R. Expression of ATPbinding cassette membrane transporters in rodent and human Sertoli cells: relevance to the permeability of antiretroviral therapy at the blood-testis barrier. J Pharmacol Exp Ther 2012; 340: 96-108.

168. Bart J, Hollema H, Groen HJ, de Vries EG, Hendrikse NH, Sleijfer DT, Wegman TD, Vaalburg W, van der Graaf WT. The distribution of drug-efflux pumps, P-gp, BCRP, MRP1 and MRP2, in the normal blood-testis barrier and in primary testicular tumours. Eur J Cancer 2004; 40: 2064-70.

169. Augustine LM, Markelewicz RJ Jr, Boekelheide K, Cherrington NJ. Xenobiotic and endobiotic transporter mRNA expression in the blood-testis barrier. Drug Metab Dispos 2005; 33: 182-9.

170. Boockfor FR, Morris RA, DeSimone DC, Hunt DM, Walsh KB. Sertoli cell expression of the cystic fibrosis transmembrane conductance regulator. Am J Physiol 1998; 274: C922-30.

Received February 22, 2012; accepted April 11, 2012 